\title{
Commentary: Reflecting Psychological Eloquence through Figure Paintings
}

\author{
Nur Azeema Suhaimi ${ }^{1}$ \\ ${ }^{1}$ Department of Fine Art, Faculty of Art and Design, Universiti Teknologi MARA, \\ Perak Branch, Seri Iskandar Campus, 32610 Seri Iskandar, Perak, MALAYSIA \\ Email: 1azeema@uitm.edu.my
}

Published: 28 September 2019

\begin{abstract}
eISSN: 2550-214X (C) 2019. The Authors. Published for Idealogy Journal of Arts and Social Science by UiTM Press. This is an Open Access article distributed under the terms of the Creative Commons Attribution-NonCommercial-NoDerivatives License (http://creativecommons.org/licenses/by-nc-nd/4.0/), which permits non-commercial re-use, distribution, and reproduction in any medium, provided the original work is properly cited, and is not altered, transformed, or built upon in any way.
\end{abstract}

Beauty is one of the most mysterious commodities. The idea of "beautiful" itself varied across cultures and keep changing over time (Fallon, 1990). In this century of shifting relations and alliances between despotic rulers, the portrait had its diplomatic function. Besides providing a reminder at home to officials and courtiers of the governing power, the ruler-image was a symbol of international exchange while, the artist himself an international figure.

This writing intended as a response on women and beauty standards that has been reflected by the artist through her paintings. Nowadays, becoming physically attractive is likely to be a major need in woman's life. Physical appearance did give a woman a big impact on how peers and major society will look at them as a woman.

During the age of 18 onwards, most female teenager assumed that being pretty is everything. Once people have decided to judge you simply from your looks, it became the most scrutinized quality you will have. Other than that, facial beauty is the primary adjective the society could describe you by. Other qualities come second. When one woman's entire life is obviously based on a single adjective, she began to think that is all she is being defined by. It also involved their acceptance of individual wellbeing. And here is where most women started to become paranoid about themselves which finally lead them to be a teenager, growing up with an extreme level of insecurity. Women who is highly insecure about their looks have made it easier for the society to convince them that they must follow the beauty standards and willing to accept the significant health risks that comes after (Saltzberg \& Chrisler, 2006).

We believe each of us women, does not like to refer ourselves as a non- pretty woman. We all know we are attractive to those who matter but that does not mean we have never experienced rejection and unkindness. In reality, our society has created the eventual trap; the prettier you, are the more welcomed you would get.

The hardest thing a woman has to deal with is social rejection. When it comes to members of her own sex, their peers, she is often an outcast. As written by Christy Stewart in Top 10 Things That Make a Woman Threatening to Other Women in PairedLife.com online article, the number 1 threat is beauty. Women of any age can be confident or insecure about their appearances. If someone feels that their appearance differs from social's beauty standards, they may project their insecurity onto people who fit the standard more closely.

As becoming physical attractive is now a major need in a woman's life, most women decided to take risk in upgrading their self-need for beauty. It is either through the usage of makeup or by applying various kinds of cosmetic products on their body and face. However, a big portion of these women lose their original beauty due to being too obsessed of using the fast way which finally lead to their own facial disfigurement and health issues. 
In this artwork, a single figure had been chosen as a subject, focusing on her face as there is nothing more expressive as the feelings that pass by a glance. Here, it can be seen clearly an image of a woman in which the face has been destroyed, showing some provocation and satirize version the women itself. Taking some effort to look beautiful is not a crime but deciding to sacrifice your original beauty by choosing the fast way to change your physical appearance just to impress the society is totally not worth it. Attaining the beauty standards require a lot of money. Expensive cosmetics are thought to be the most effective although their ingredients might cost the same as the less expensive one (Lakoff \& Scherr, 1984; Chapkis, 1986).

Apart from that, plastic surgery has become accepted and so common nowadays. Plastic surgery can rebuild a face and to almost any parts of the body too. Thus, not surprise to know, most plastic surgery patients are women (Hamburger, 1988). However, spending money with high hope soon to be beautiful but turns out becoming a total loser will definitely increase the level of insecurity. Besides, you will lose your original beauty, health, and wealth. In the end, you are the one who is suffering more and more while the society does not care at all.

Reimagining the disfigurement of standard beauty on a female portrait representing how most of the women nowadays value themselves. Beauty has been defined in so many ways. What the artist has discovered is that beauty is simple. Beauty is happiness. However, beauty is often distorted, misunderstood and shadowed by a wide amount of conflicting pressures. It is something most women endlessly aiming for, rather than see in the true essence of their happiest moments.

Beauty is in the heart, always in the heart, and the way it shines through. We are all unique, with experiences and memories that tie together creating our very own version of beauty. We are women of different shapes, sizes, colours, and heritage. We are mothers, daughters, and grandmothers. We are achievers, innovators, activists, and inspirations. We are what we live for. Trying to fit into a blanket of our social beauty standards would only destroy your inner self, you are not being yourself and you are not happy inside. As the sayings said by Marilyn Monroe, "Wanting to be someone else is a waste of the person you are".

Our bodies are simply a shell that allows us to radiate these experiences and accomplishments through. They are a case that displays our happiest and most incredible experiences for the world to share with us. No culture, company nor concept could ever define beauty. It is composed of the moments that draw upon our strength and consume us with the remarkable and intoxicating experience of being alive.

The image's destruction is the main process in making this piece of art. For the artist, destruction is a form of creation. In order to create this art piece, the artist applied bleaching technique to destroy a few parts of the portrait. Not just bleaching, the artist then redrew the image with some provocation and satirizes the women itself. Apart from that, the process itself represents the story behinds. The excitement of major women to be beautiful in fast way but ended up destroying their self and vanish their natural beauty.

Thus, stop comparing yourself to other people. Stop building your own self insecurities and start appreciating who you are. Bear in mind, you cannot be someone else nor the other person can be you. Each person is a one of a kind. Now, that is what we call 'beautiful'.

\section{REFERENCES}

Chapkis, W. (1986). Beauty secrets: Women and the politics of appearance. South End Press.

Conway, D. (2015, May 14). Beauty Advice From Marilyn Monroe The Modern Woman Needs To Hear. Retrieved from https://aplus.com/a/10-Beauty-Quotes-By-Marilyn-

Monroe?no_monetization=true 
Fallon, April. (1990), Culture in the mirror: Sociocultural determinants of body image. In Thomas Cash \& Thomas Pruzinsky (Eds.), Body images: Development, deviance, and change (pp. 80-109). New York: Guilford Press.

Hamburger, A.C. (1988, May). Beauty quest. Psychology Today, 22, 28-32. Hatfield, Elaine, \& Sprecher, Susan. (1986). Mirror, mirror: The importance of looks in everyday life. Albany: State University of New York Press.

Lakoff, Robin T., \& Scherr, Raquel L., (1984). Face value: The politics of beauty. Boston: Routledge $\&$ Kegan Paul.

Saltzberg, E. A., Chrisler, J. C., \& Disch, E. (2006). Beauty is the beast: Psychological effects of the pursuit of the perfect female body. Moral Issues in Global Perspective: Volume 2: Human Diversity and Equality, 2, 142. 